\title{
THE W'TO SEAL PRODUCTS CASE: DOCTRINAL AND NORMATIVE CONFUSION
}

\author{
Joel Trachtman*
}

The negotiators and drafters of the Agreement establishing the World Trade Organization (WTO) ${ }^{1}$, which includes the General Agreement on Tariffs and Trade 1947 (GATT) ${ }^{2}$ and the Agreement on Technical Barriers to Trade (TBT) ${ }^{3}$, as well as other subagreements dealing with domestic regulation, such as the Agreement on Sanitary and Phytosanitary Measures (SPS) ${ }^{4}$, did not do a great job of doctrinal integration among the different documents that comprise the WTO Agreement. To be fair, at the end of the Uruguay Round, the hour was late and they may have felt that the basic ideas were sufficiently clear that it could all be sorted out in litigation. But in several contexts, including within the original GATT, the text of which dates from 1947, they covered the same ground in multiple places, without stating clearly how the different norms relate to one another, and without articulating plausible reasons for different treatment. ${ }^{5}$ For example, why is different language used for national treatment in three different places within Article III of GATT, and why is that language different from the language that appears to have the same purpose in the TBT Agreement or in the SPS Agreement?

Two seemingly innocent principles of interpretation developed in the WTO dispute settlement system have contributed to the problem. One is the principle of cumulative application, which, while it does not apply in every context, generally applies to say that a particular national measure must comply with all applicable WTO rules. The principle of cumulative application says that there is no need to choose the most suitable norm and exclude others, and is a deferential way for panelists and Appellate Body members to approach the treaties: if the Member States included multiple rules purporting to apply to the same thing, and did not specify how they relate to one another, the judge simply applies them all. According to this approach, there is no need for the judge to exercise judgment to select the applicable rule.

But the principle of cumulative application may neglect part of the drafters' intent: implicit in the fact that a potentially applicable rule does not restrict the relevant measure is a decision of the Member States to permit that conduct. This permissive "rule" is juxtaposed with another restrictive rule, and under the cumulative application approach, the restrictive rule always prevails. Yet this is not necessarily consistent with the context,

* Professor of International Law at the Fletcher School, Tufts University.

Originally published online 25 June 2015.

${ }^{1}$ WTO Agreement, Apr. 15, 1994, Marrakesh Agreement Establishing the World Trade Organization, 1867 UNTS 154.

2 General Agreement on Tariffs and Trade 1994, Apr. 15, 1994, Marrakesh Agreement Establishing the World Trade Organization, Annex 1A, 1867 UNTS 187.

${ }^{3}$ Agreement on Technical Barriers to Trade, Apr. 15, 1994, Marrakesh Agreement Establishing the World Trade Organization, Annex 1A, 1868 UNTS 120.

${ }^{4}$ Agreement on the Application of Sanitary and Phytosanitary Measures, Apr. 15, 1994, Marrakesh Agreement Establishing the World Trade Organization, Annex 1A, 1867 UNTS 493.

5 See Gabrielle Marceau \& Joel P. Trachtman, A Map of the World Trade Organization Law of Domestic Regulation of Goods: The Technical Barriers to Trade Agreement, the Sanitary and Phytosanitary Measures Agreement, and the General Agreement on Tariffs and Trade, 48 J. WORLD TRADE 351 (2014). 
object, and purpose of the treaty, which, along with ordinary meaning, are the guiding factors in interpretation under the Vienna Convention on the Law of Treaties. ${ }^{6}$

The other principle of interpretation that has caused trouble is the related rule of effet utile, meaning that all treaty provisions, words, and differences in terms used are to be given meaning: judges are to respect differences in treaty language, and not to determine that different language was used to mean the same thing. Given the imprecision of drafting evident in the WTO Agreement, this has turned into a dangerous rule. In the context of the Appellate Body's GATT Article III jurisprudence, it has applied the principle of effet utile to give meaning to slightly different formulations within Article III relating to taxes and product regulation, respectively, in a way that has left little room for distinctions based on regulatory purposes. Based on the explicit reference in the second sentence of Article III:2 to the "so as to afford protection" language of Article III:1, the Appellate Body has restricted consideration of whether national measures are applied "so as to afford protection" to circumstances in which dissimilar taxes are applied to products that are not "like" but are "directly competitive or substitutable."

Both cumulative application and effet utile are deferential to the treaty language, by virtue of the fact that they circumscribe the discretion of judges, but they are not necessarily deferential to the treaty parties, who may have hoped that judges would help them to implement the treaty object and purpose. Both cumulative application and effet utile are unsympathetic to less than perfect drafting. The WTO Appellate Body has also used a similar textualist approach to punish weak drafting in the China—Raw Materials ${ }^{7}$ and China—Rare Earths ${ }^{8}$ cases, $^{2}$ in which the Appellate Body has determined that the exceptions for domestic regulatory measures in Article XX of GATT are not available in connection with the prohibitions of export duties in China's Protocol of Accession.

In this comment, I explain how these approaches have made the Appellate Body's approach to critical provisions of WTO law relating to domestic regulatory measures that restrict trade incoherent, and normatively unattractive, as exemplified in the EC-Seal Products ${ }^{9}$ decision.

\section{What is the Scope of Application of the TBT Agreement, and How Does it Relate to the GATT?}

Nothing in the TBT Agreement states that where it applies the relevant GATT provisions do not apply, or vice versa. So, under the principle of cumulative application, these obligations are applied cumulatively. The TBT Agreement is generally tougher to comply with than GAT'T, because it adds direct necessity requirements and lacks a general exceptions provision, so domestic regulation is subject to less strict review if the TBT Agreement is inapplicable. The relevant restrictions of the TBT Agreement apply to "technical regulations," as defined in Annex 1.1. The Panel in EC-Seal Products determined that the European Union (EU) "prohibition on seal-containing products ... lays down a product characteristic in the negative form," and therefore falls within the definition. ${ }^{10}$

${ }^{6}$ Vienna Convention on the Law of Treaties, May 23, 1969, 1155 UNTS 331.

7 Appellate Body Report, China-Measures Related to the Exportation of Various Raw Materials, WT/DS394/AB/R, WT/DS395/AB/R, WT/DS398/AB/R (Adopted Feb. 22, 2012).

8 Appellate Body Report, China-Measures Related to the Exportation of Rare Earths, Tungsten, and Molybdenum, WT/DS431/AB/R, WT/DS432/AB/R, WT/DS433/AB/R (Adopted Aug. 29, 2014).

9 Appellate Body Report, European Communities-Measures Prohibiting the Importation and Marketing of Seal Products, WT/DS400/AB/R, WT/DS401/AB/R (Adopted June 18, 2014) [hereinafter Appellate Body Report, EC—Seal Products].

${ }_{10}$ Panel Report, European Communities-Measures Prohibiting the Importation and Marketing of Seal Products, WT/DS400/R, WT/DS401/R (Adopted June 18, 2014). 
The Panel determined that the EU measure laid down a product characteristic "in the negative form" by requiring that products not contain seal. ${ }^{11}$ However, the Panel treated the exceptions for indigenous communities (IC) and marine resource management (MRM) as "applicable administrative provisions", and therefore did not, according to the Appellate Body, examine the EU's measure as a whole. ${ }^{12}$ The Appellate Body found that merely being an "applicable administrative provision" is insufficient, standing alone, to constitute the measure a technical regulation, and saw no basis in Annex 1.1 on which to "suggest that the identity of the hunter, the type of hunt, or the purpose of the hunt could be viewed as product characteristics". ${ }^{13}$

In the end, the Appellate Body was not persuaded that the restriction on seal content was the main feature of the EU's measure. Rather, according to the Appellate Body, the main feature of the measure involves the identity of the hunter and purpose of the hunt, and therefore the measure did not lay down product characteristics. ${ }^{14}$ So, at the core of the Appellate Body's reversal of the Panel's finding that the EU measure was a technical regulation is a determination that the EU measure was focused on the process rather than the product. The complainants requested the Appellate Body to complete the analysis by determining whether the EU measure was a sufficiently product-related process or production method (PPM) within Annex 1.1, but the Appellate Body found that there was insufficient evidence with which to complete the analysis. It did note that "the line between PPMs that fall, and those that do not fall, within the scope of the TBT Agreement raises important systemic issues." 15

Therefore, the EU measure was not properly evaluated under the TBT Agreement, and the Appellate Body focused the rest of its opinion on the panel's analysis under GATT.

This issue presents a definitional puzzle. The EU measure bases its prohibition on two aspects of a product: (1) its seal content, and (2) whether it qualifies for the IC or MRM exception. So it is clearly a combined product and process regulation, where the process parameters are not examined unless the product parameter is met. It is not clear how the Appellate Body reaches the conclusion that the "core" of the regulation is process oriented, and it would be interesting to know why the "core" is important, and how it is defined. So, the Appellate Body has left this important systemic issue of the scope of applicability of the TBT Agreement unresolved.

The Failure to Include a Right-to-Regulate-Type Exception in the TBT Agreement, and the Appellate Body's "Fix" in Clove Cigarettes

Since the advent of the WTO, scholars and policy makers have wondered about the fact that the TBT Agreement contains most favored nation (MFN) and national treatment obligations, as well as other obligations, but lacks a set of general exceptions such as that found in Article XX of GATT. There is no evidence that the failure to include such exceptions was intentional, and it can be understood as an instance of imperfect drafting.

When this issue came up in the U.S._-Clove Cigarettes case, the Appellate Body engaged in a creative interpretation to find that "the context and object and purpose of the TBT Agreement weigh in favour of interpreting the 'treatment no less favourable' requirement of Article 2.1 as not prohibiting detrimental impact on imports that stems exclusively from a legitimate regulatory distinction."16 Indeed, in addition to the relevant recitals and Article 2.2 of the TBT Agreement, the Appellate Body referred to the exceptions in Article XX of GATT as

11 Appellate Body Report, EC-Seal Products, supra note 9, at para. 5.25.

$12 \underline{I d}$. at para. 5.27 .

$13 \underline{I d}$. at para. $5.43-45$.

${ }^{14} \underline{I d}$. at para 5.58 .

${ }^{15} \underline{I d}$. at para. 5.68 .

16 Appellate Body Report, United States-Measures Affecting the Production and Sale of Clove Cigarettes, paras. 1.80-82, WT/DS206/AB/R (Adopted Apr. 24, 2013). 
part of the context for interpretation of the TBT Agreement. To be clear, in Clove Cigarettes, the Appellate Body found that a determination of discrimination in the TBT context requires assessment of the aim of the regulatory measure.

In Seal Products, the EU argued, and the panel accepted, that the "stems exclusively from a legitimate regulatory distinction" standard developed in Clove Cigarettes should also be applied to interpretation of Article III:4 of GATT. That is, a measure should not be found to impose less favourable treatment within the meaning of Article III:4 if its detrimental impact stems exclusively from a legitimate regulatory distinction. The EU also argued that the MFN obligation in Article I:1 should be read the same way, despite the fact that the term "less favourable treatment" is not included there. The EU simply sought consistent treatment across agreements: if discrimination requires assessment of the aim of the regulatory measure under the TBT Agreement, discrimination should be determined similarly under GATT. This approach to interpretation is respectful of context and object and purpose, and promotes substantive consistency in the face of suboptimal drafting.

The Appellate Body rejected these arguments on a text-focused basis. In doing so, the Appellate Body extended a line of WTO jurisprudence to the effect that discrimination cases, other than under Article 2.1 of the TBT Agreement, are to be determined based purely on competitive factors. That is, imported and domestic products (or under MFN imported products from different countries) would be determined to be "like" or "directly competitive or substitutable" based purely on competitive factors. Furthermore, in EC-Seal Products, the Appellate Body held for the first time that "less favourable treatment" under Article III:4 would be determined purely by reference to the effect on competition. ${ }^{17}$ The evocative language of the Appellate Body's 2001 report in the EC-Asbestos ${ }^{18}$ case, suggesting in paragraph 100 that a broader analysis is possible, was interpreted into irrelevance by the current Appellate Body in the EC-Seal Products decision.

Let me emphasize the implication of the Appellate Body's decision: regulatory purposes are now irrelevant to determinations of discrimination under GATT, but not under the TBT Agreement. ${ }^{19}$ Note the irony: the Appellate Body "fixed" the TBT Agreement in Clove Cigarettes, but in doing so created an inconsistency between rules with similar language in the TBT Agreement and in the GATT.

The EU made the argument that this holding would leave a narrower right to regulate in the GATT than that which was found to exist in Article 2.1 of the TBT Agreement under the Appellate Body's U.S.—Clove Cigarettes decision to respect "legitimate regulatory distinctions" under that provision-which would be inconsistent with what most people think was the negotiators' and drafters' intent. As Greg Shaffer and David Pabian point out in their recent AJIL case commentary, this leaves the jurisprudence of domestic regulation inconsistent. ${ }^{20}$ After all, the GATT only has Article XX, which has a limited list of permissible regulatory purposes, and for which the respondent largely bears the burden of proof. In response to the EU's assertion of this point, the Appellate Body responded to the effect that the EU was unable to articulate any regulatory purpose not listed in Article XX of GATT. However, it is easy to see in this case that the protection of indigenous people is not listed in

${ }^{17}$ Appellate Body Report, EC-Seal Products, supra note 9, at para. 5.101.

18 Appellate Body Report, European Communities-Measures Affecting Asbestos and Products Containing Asbestos, WT/DS135/AB/R (Adopted Apr. 5, 2001).

19 The Appellate Body asserts that the same things that form the basis for a regulatory distinction could also form the basis for a difference in competitive situation, but this does not mean that regulatory distinctions have any independent role. Indeed, the reason for regulation is often that the marketplace fails sufficiently to make relevant distinctions.

${ }^{20}$ Gregory Shaffer \& David Pabian, European Communities_Measures Probibiting the Importation and Marketing of Seal Products, 109 AJIL 154 (2015). 
Article XX, and the United States has recently pointed out in the U.S.—COOL ${ }^{21}$ litigation that consumer protection is not included either.

Robert Hudec, one of the great early GATT law scholars, and a legal realist, argued that no matter what tribunals say that they analyze in de facto discrimination cases, they will actually be examining the aims and effects of the national measure. ${ }^{22}$ In examining aims, a tribunal would determine whether the different treatment stems from a legitimate regulatory distinction-just as the Appellate Body determined was necessary under Article 2.1 of the TBT Agreement in U.S._C Clove Cigarettes. The WTO Appellate Body rejected the aims and effects test early in its Japan-Alcoholic Beverages ${ }^{23}$ decision, but much Appellate Body jurisprudence can be understood in these terms. ${ }^{24}$ The aim and effects test imposes a significant burden of judging on judges-it is a less formally realizable test than the competition-based test of like products and less favorable treatment adopted by the Appellate Body.

Hudec hoped that WTO judges would use the aim and effects test to defer to national regulatory autonomywhere there is a respectable nonprotectionist aim, and where the adverse effects on trade are not excessive in relation to the nonprotectionist regulatory goal. The Appellate Body in EC-Seal Products has banned discussion of regulatory goals from Article III discourse. This will often put the burden of proof on the regulating state to identify a basis for exception under Article XX.

The principle of cumulative application will mean that the stricter of the TBT Agreement and the GATT obligations regarding domestic regulation will rule. Under the EC-Seal Products decision, there will be circumstances in which the GATT will be the more restrictive of the two obligations-where the national measure stems exclusively from a legitimate regulatory distinction, and is therefore found permissible under the TBT Agreement, but where it has differential effects on products in competition with one another and therefore violates Article III:4 of GATT.

EC - Seal Products represents what one may only hope will be a turning point in which the Appellate Body will apply Article XX liberally in order to ensure that states have sufficient regulatory autonomy, now that it has removed consideration of regulatory purpose from Article III discussion. Perhaps also, the Appellate Body will emphasize context, and object and purpose, over textualism, cumulative application, and effet utile in order to bring consistency and rationality to the regulatory exceptions in WTO law.

21 Appellate Body Report, United States_Certain Country of Origin Labelling (COOL) Requirements, WT/DS384/AB/R, WT/DS386/AB/R (Adopted July 23, 2012).

22 Robert E. Hudec, GATT/WTO Constraints on National Regulation: Requiem for an “Aim and Effects” Test, 32 INT'L LAW. 619 (1998).

${ }^{23}$ Appellate Body Report, Japan—Taxes on Alcoholic Beverages, WT/DS8/AB/R. WT/DS10/AB/R, WT/DS11/AB/R (Adopted Nov. 1, 1996).

24 See Amelia Porges \& Joel P. Trachtman, Robert Hudec and Domestic Regulation: The Resurrection of Aim and Effects, 37 J. WORLD TRADE 783 (2003). 